\title{
Królestwo Belgii wobec kryzysu imigracyjnego (2015-2016)
}

\section{Wstęp}

Od lata 2015 r. do marca 2016 r., sytuacja w Europie charakteryzowała się bezprecedensowym napływem azylantów, wywołaną przez wyjątkowo trudny i globalny kryzys humanitarny (wojny domowe na Bliskim Wschodzie i w Północnej Afryce). Kwestia ochrony międzynarodowej, jak i schronienie dla uchodźców stanęła w centrum zainteresowania świata polityki, mediów, jak i zwykłych obywateli. Przejmujące obrazy zdesperowanych imigrantów na chwiejnych łodziach lub zdjęcie małego Aylana, zwróciły uwagę na przerażającą rzeczywistość poza granicami Unii Europejskiej. Wiele państw nie radziło sobie z nową sytuacją, wiele podejmowanych działań było nieprzemyślanych, chaotycznych. Niektóre kraje budowały ogrodzenia wzdłuż granic, inne wprowadziły i nadal kontynuują kontrole graniczne (pomimo umowy z Turcją z marca 2016 r.). Komisja Europejska ustanowiła system kwot imigrantów dla poszczególnych państw, aby jak najbardziej odciążyć niedających sobie rady z napływem uchodźców Włochów czy Greków. W przypadku Belgii kwota ta wyniosła około 4564 uchodźców. „Belgia przez długi czas odznaczała się wyraźnie w dziedzinie polityki azylowej, gdyż jej zaangażowanie było znacznie wyższe od średniej europejskiej”, można było się dowiedzieć z wypowiedzi Theo Franckena, sekretarza stanu ds. azylu i migracji. Urzędujący premier Charles Michel na łamach prasy we wrześniu 2015 r. wyraził zadowolenie z dotychczas osiagniętych rezultatów stwierdzając, że „podjęliśmy wyzwanie, stworzyliśmy tysiące schronów, wzmocniliśmy administrację, pozostajemy w świetnej współpracy z gminami, stowarzyszeniami jak np. Czerwony Krzyż..., ale chcę być szczery: to będzie trudne, a jeszcze trudniejsze w najbliższych miesiącach" (Opvangcrisis zal alleen maar moeilijker worden, 2015).

\section{Doświadczenia historyczne}

W XIX wieku podobnie jak inne państwa europejskie, Królestwo Belgii rozpoczęło kolonizację ograniczoną głównie do Afryki. Perłą w jej koronie było Kongo Belgijskie (dzisiejsza Demokratyczna Republika Konga) na dalszym miejscu znajdowała się Ruanda-Urundii (dzisiejsza Rwanda i Burundi).

Belgia w przeszłości nie miała wygórowanych ambicji kolonialnych, w przeciwieństwie do wielu innych państw takich jak Wielka Brytania, Francja, Portugalia, Hiszpania czy nawet Holandia. Pod koniec XIX wieku, jednakże król belgijski Leopold II, stał się mistrzem na arenie międzynarodowej w wyścigu kolonialnym. Udało mu się skolonizować obszar w sercu Afryki osiem razy większy od jego własnego 
królestwa, interesujący pod względem zawartości bogactw naturalnych. Kolonia była bezwzględnie eksploatowana w zasadzie przez jednego człowieka - króla Leopolda II, traktującego ten obszar i ludzi, jako osobiste dobra, co przyczyniło się do późniejszych dramatycznych wydarzeń (Vanthemsche, 2011, s. 215-216).

Dzisiejsza Demokratyczna Republika Konga, formalnie stała się kolonią od 1908 r., ale państwo to było już od 1885 r. w rękach króla Leopolda II. Od 1885 do 1908 r. Kongo posiadało pewne przywileje i wolności, w którym inaczej niż w Belgii, monarcha posiadał pełnię władzy i nie był ograniczony konstytucją (Reybrouck, 2011, s. 21 i 71). W literaturze podkreśla się, iż ekspansja króla Leopolda II, była nie tylko spowodowana korzyściami finansowymi, ale także nadzieją na dostarczenie socjalnej i politycznej stabilności metropolii. Niestety, wyzyskowi Konga towarzyszył terror wobec mieszkańców i od 1900 r. odbijało się to coraz szerszym echem w Europie. W związku z szerokimi protestami na tym tle w samej Belgii, w 1908 r. postanowiono Kongo oficjalnie uznać za kolonię państwa belgijskiego i odtąd nazywano ją „Kongiem Belgijskim" (Ibidem, s. 74).

Po drugiej wojnie światowej idea niepodległości nabrała coraz wyraźniejszego kształtu. Zamieszki w stolicy Leopoldville, skłoniły rząd belgijski w oświadczeniu z 13 lutego 1959 r. do uznania prawa Konga Belgijskiego do niepodległości. W styczniu 1960 rozpoczęła się debata w Brukseli przy okragłym stole na temat przyszłości tego obszaru. Rząd belgijski zgodził się, że kolonia stanie się niezależnym państwem 30 czerwca 1960 r. Ze względu na problemy w dawnym Kongu Belgijskim, po odzyskaniu niepodległości w 1960 r., ale również później w związku z innymi kryzysami, wielu Belgów wyemigrowało stamtąd przede wszystkim do Republiki Południowej Afryki, gdzie starali się zbudować nowe życie.

Nie ulega wątpliwości, iż kongijska diaspora w Belgii jest wynikiem spuścizny kolonialnej. W tym kontekście warto przytoczyć badanie przeprowadzone przez belgijski dziennik „Mondial Niews” w 2010 r. na temat rzeczywistych doświadczeń kongijskich Belgów w Belgii i ich związku z państwem pochodzenia („Mondial Niews”; Daele, $2010)^{1}$. Pierwsze zadane pytanie dotyczyło wskazania przez ankietowanych swojego „domu”. Kongijczycy, którzy urodzili się w Belgii, czy przyjechali w młodym wieku, odpowiadali na to pytanie inaczej niż ci, którzy przybyli do Belgii w późniejszym czasie. Pierwsza grupa często reagowała z entuzjazmem, odpowiadając, iż ich dom jest w Antwerpii czy Brukseli. Dorośli Kongijczycy nadal nazywali swoim domem Kongo, podkreślając zwykle, że przybyli do Belgii z myślą, że pozostaną jedynie czasowo, np. na okres studiów. Ci, którzy urodzili się w Belgii, nazywają Belgię swoim domem, dodając, iż w Kongo, nazywają ich „dziećmi Europy” i kiedy np. spędzają czas z przyjaciółmi w Belgii to czuję się tak samo. „Mamy tę samą tożsamość, ale nasza skóra zdradza nasze korzenie". Inna osoba, która przybyła do Belgii, jako dziesięciolatek dodała, iż zastanawia się, kim jest. Nie czuje się Belgiem i pyta siebie czy jest Kongijczykiem, skoro nie zna języków (lingala i suahili), nie była w Kongo od osiemnastu lat. Z jednej strony „w swojej głowie” jest Belgiem, ale ciagle nieak-

1 „Mondial Niews” „MO” podjął inicjatywę przeprowadzenia badania wobec grup fokusowych w Gandawie, Antwerpii, Liege i w Brukseli. Na podstawie tego badania, został opracowany dwumiesięcznik „Imagine - demain le monde” wspólnie z Centre Bruxellois d'Action Interculturelle (CBAI) 
ceptowanym w społeczeństwie. Inną kwestią, z jaką przyszło się zmierzyć badanym, jest rasizm. Osoby te bardzo często podkreślały, iż podczas szukania domu lub pracy, odnosiły wrażenie, że ich kolor skóry przeszkadzał. „Jak tylko słyszą akcent, widzą kolor skóry, można dostrzec krótkie wahanie, a po krótkiej chwili odpowiedź, że domu lub pracy już nie ma”.

Część kongijskiej diaspory mieszka również w biedniejszych dzielnicach, co również przyczynia się do ich dyskryminacji. Następnie podkreślano również, iż zarówno Gandawa, jak i Antwerpia, generalnie Flandria, charakteryzuje się większym rasizmem niż francuskojęzyczna część Belgii. „Pewnego dnia byłem na stacji we Flandrii. Rozmawiałem przez telefon. Biały człowiek, Flamand, który siedział obok mnie, powiedział do mnie: »Hej, czarniutki, wiesz, że my tutaj nie lubimy czarnych«. Tak po prostu. Tak głośno, aby każdy mógł usłyszeć. Byłem w szoku”. Matka dzieci z Antwerpii dodała, że „w Brukseli dzieci dowiadują się, że są dzieci o różnym kolorze skóry i że po prostu trzeba je zaakceptować". Także język we Flandrii jest dodatkowym utrudnieniem. Prawie wszystkie osoby po przybyciu do Belgii z Kongo mówią po francusku, a nie po holendersku. „Jeśli mówisz po francusku, czasami odmawiają odpowiedzi”. „Przekonałem się, że w Antwerpii, chętniej zamiast w języku francuskim odpowiadają w języku angielskim. Nigeryjczycy mają zatem łatwiej niż my”. Niektórzy spodziewali się, że będą lepiej traktowani, jako Kongijczycy. „Zapomnij o tym. Jesteśmy czarni jak inni Afrykanie" (Ibidem).

Czy faktycznie we Flandrii przejawy rasizmu są większe niż w francuskojęzycznej Walonii? Nie ulega wątpliwości, że we francuskojęzycznej części można także doświadczyć zachowań o podłożu rasistowskim. Poza tym Belgowie starszego pokolenia nie są otwarci na nowych przybyszów. Młodzi Belgowie natomiast są bardziej zainteresowani poznaniem innej kultury. Nie należy także zapominać, że zarazem u Kongijczyków, którzy posiadają bardzo dobrze płatną pracę w Belgii czy w Kongo zdarza się negatywne postrzeganie własnych rodaków: „moje uprzedzenia wobec czarnych wynika $\mathrm{z}$ tego, że są leniwi. Białych uważam za pracowitych i dobrze zorganizowanych" (Ibidem).

\section{Integracja pod znakiem zapytania}

Od wielu lat Belgia charakteryzuje się napływem imigrantów, przede wszystkim z państw europejskich, jednakże $w$ związku z kryzysem imigracyjnym trwającym od 2015 r. w Belgii de facto również odnotowano wysoki odsetek imigrantów z Bliskiego Wschodu oraz Afryki Północnej.

Jednakże wobec imigracji dominuje negatywny stosunek i niepewność także w wypowiedziach osób na wysokich stanowiskach w państwie. Leopold Lippens burmistrz Knokke-Heist podczas wywiadu dla „Sudpresse” powiedział: „zamknijmy migrantów w obozie jak Guantanamo, ale bez tortur" (wypowiedź dotyczyła migrantów, którzy w związku z likwidacją nielegalnego obozowiska przygranicznego z Belgią, Calais (Francja), potencjalnie mogliby przybyć do Belgii) (Baert, Roy, 2016).

Podjęta przez imigrantów czy migrantów droga ze względów politycznych czy ekonomicznych, opatrzona jest perspektywą zbudowania nowego, lepszego życia, 
często pełnego ambicji i pozytywnego nastawienie do pracy i postępu. Negatywny obraz wzmacnia się również poprzez nieudane projekty integracyjne i widoczne w społeczeństwie ubóstwo, przestępczość czy radykalizację religijną.

Dodatkowo, negatywny stosunek wobec imigrantów umocnił się w związku z niedawnymi atakami terrorystycznymi (zamachy z 22 marca 2016 r.) dokonanymi w „stolicy Europy” przez radykalnych islamistów. W Belgii, a zwłaszcza w Brukseli występuje duża koncentracja umiarkowanych wyznawców islamu, wobec których często dochodziło do różnych słownych gróźb czy innych incydentów. Jednak dzielnica Molenbeek z 95000 mieszkańców, zwana również „,wylęgarnią dżihadystów”, jest jednocześnie jedną z najbiedniejszych w Belgii. Około 30\% stanowią tutaj sfustrowani bezrobotni (Hoe Molenbeek internationaal op de kaart werd gezet, 2015; Evolutie van de Brusselse arbeidsmarkt, 2015, s. 7).

W Molenbeek ubóstwo jest względne. Nie ma głodu, nie ma bezdomności, nie brak infrastruktury medycznej, nie ma braku szkół. W porównaniu do przeciętnego poziomu życia w Maroku i Egipcie, średni standard życia w Molenbeek jest porównywalny do tamtejszej klasy średniej. Podobnie jak w każdym innym państwie Europy Zachodniej, wiele instytucji i organizacji belgijskich oferuje wsparcie, gdy rodziny potrzebują mieszkań, żywności, edukacji i opieki zdrowotnej. Mają szanse na sukces w społeczeństwie, znacznie większy niż w państwie swojego pochodzenia. Wysokie wskaźniki bezrobocia wśród muzułmanów niewiele mają wspólnego z wykluczeniem i dyskryminacją. Duża część populacji migrujących radzi sobie wystarczająco, ale ponad połowa, nie chce pozbyć się mentalnych i kulturowych uwarunkowań, które wynoszą z domu rodzinnego. Kwestia równości i praw dla kobiet, braku rozdziału państwa od kościoła, nieodpowiednia edukacja, nadmierna religijność to wszystko można zauważyć na obszarach o wysokim wskaźniku imigrantów, w tym zwłaszcza w Molenbeek (Brussels Observatorium voor de Werkgelegenheid, Territoriale benadering van de werkloosheid van allochtone vrouwen of vrouwen van allochtone afkomst in het Brussels Gewest, 2012, s. 2-3).

Po atakach terrorystycznych, podobnie jak w wielu innych państwach unijnych, pojawiły się także negatywne komentarze wobec polityki imigracyjnej wyznaczonej w Unii Europejskiej przez rząd kanclerz Angeli Merkel. Po atakach terrorystycznych w Brukseli wśród elit do najbardziej charakterystycznych pytań należały: Co my, Europejczycy, naszym muzułmanom uczyniliśmy? Jak wyznawcy religii, która jest dumnie nazywana „religią pokoju” mogą popełniać tego rodzaju okrucieństwa? Wielu belgijskich intelektualistów twierdziło, że Belgia musiała zrobić „coś strasznego” by na takie dramaty zasłużyć. W ich rozumowaniu furia terrorystów i radykalizacja musi być reakcją na ich nieludzkie traktowanie przez Zachód. Bezpieczniej jest winić własne społeczeństwo i warunki społeczno-ekonomiczne niż winić pojęcia religijne i kulturowe, którymi terroryści zatruwają swoje umysły. Leon de Winter, nowelista i polityczny komentator dodał „Co my im zrobiliśmy? Otworzyliśmy nasze miasta, nasze domy, nasze portfele. A w naszych świątyniach świeckich - naszych stacjach metra i na lotniskach i w teatrach - ich synowie są samobójcami, dodatkowo zabierając naszych synów i córki z nimi. Nie mamy za co przepraszać" (Europe’s Muslim hate the West, 2015).

Belgijski sekretarz stanu ds. migracji i azylu, wspomniany Theo Francken, wskazuje, że kluczową sprawą jest problem kulejącej deportacji z Belgii osób niepożąda- 
nych. Jako przykład podaje się sprawcę zamachu w Charleroi, 33-letniego Algierczyka nielegalnie przebywającego w Belgii, który dwukrotnie zignorował nakaz opuszczenia terytorium Królestwa, czy Mohameda Belkaida, również Algierczyka zaangażowanego w zamachy w Paryżu (Erfenis uit het verleden die je in twee jaar niet kan opkuisen, 2016).

W opinii wielu Belgów, taka kumulacja zaniedbań w połączeniu z faktyczną bezkarnością i nieudaną polityką deportacyjną, tworzy idealne środowisko, w którym terroryści mają swobodę rozwoju ,dopóki nakaz wydalenia nie jest skuteczny, będzie szerzyć się przesłanie, że Belgia jest państwem, gdzie jak już raz postawisz nogę, to można $z$ łatwością tu pozostać, w związku z tym ataki terrorystyczne będą się powtarzać” (Ibidem). Premier Ch. Michel wskazywał, że w Belgii wciąż są dziesiątki tysięcy nielegalnych imigrantów, ale jak dodał: „dziedzictwa przeszłości, nie można oczyścić w ciągu dwóch lat” (Ibidem). Jednakże w jego ujęciu ,państwo już podąża we właściwym kierunku" a rząd podjął się realizacji około trzydziestu nowych środków bezpieczeństwa. Konkretnie wymienił zorganizowanie osobnych sądów (w ramach istniejących sądów), które zajmują się tylko sądzeniem w sprawach oskarżonych o terroryzm (Wil geen Guantanamo in België, 2016).

W grudniu 2013 roku, profesor Ruud Koopmans z berlińskiego Centrum Nauki Społecznej opublikował opracowanie pod tytułem Fundamentalizm $i$ wrogość wobec innych grup, w którym porównał wrogość wśród muzułmańskich imigrantów z zachowaniem wyznawców chrześcijaństwa w Europie Zachodniej. Prawie 60\% uważało, że muzułmanie powinni wrócić do korzeni islamu, 75\% że istnieje tylko jedna interpretacja Koranu, której każdy muzułmanin powinien się trzymać, a 65\% stwierdziło, że zasady religijne są dla nich ważniejsze niż prawo państwa w którym żyją. Wskaźnik ten u muzułmanów sunnickich pochodzenia tureckiego nieco różnił się od muzułmanów pochodzenia marokańskiego, niemniej jednak około 4\% można scharakteryzować, jako fundamentalistów (Koopmans, 2013, s. 22-23).

Integracja nie powiodło się i jest to stwierdzenie będące ostatnio często na ustach wielu czołowych belgijskich i europejskich polityków. Istnieje przekonanie, że w integracji zawiodły obie strony, zarówno „nowi”, napływowi Belgowie, jak i sami rodowici Flamandowie czy Walonowie. Prawie wszystkie wskaźniki dotyczące szczególnie edukacji i sytuacji na rynku pracy, charakteryzują bardzo niską pozycję społeczną pozaeuropejskich imigrantów i ich potomków.

$\mathrm{Z}$ punktu widzenia polityki, nie wygląda to także najlepiej. Podczas gdy liczba imigrantów rosła w ostatnich latach, nie było znaczących zmian w zakresie tworzenia nowych modeli integracji. Kwestia polityki zarządzania migracją oraz promowania integracji nadal pozostawia wiele do życzenia. Oczywiście, istnieje wiele rozporządzeń, ustaw i przepisów, gwarantujących miejsce migrantom oraz nowym Belgom w społeczeństwie. Jednakże wyniki te nie są jednoznaczne i nadal odbiegają od rzeczywistości. Taka sytuacja jest nie do utrzymania się na dłuższą metę w państwie. Niepowodzenie lub sukces integracji w społeczeństwie jest zawsze obarczone wspólną odpowiedzialnością.

Na początku września 2015 r. premier Ch. Michel zaznaczył, że osoby uprawnione do azylu muszą ,zostać wchłonięci prawidłowo, podzielać nasze wartości: wolności i demokracji, oraz powinni zostać zachęceni do pracy i nauki jednego z języków 
narodowych". Premier powtórzył również wezwanie do swojego przewodniczącego partii Oliviera Chastel o obowiązkowy program integracji. „Kto nie kwalifikuje się do azylu lub nie podziela naszych wartości demokratycznych, musi opuścić terytorium" (Opvangcrisis zal allent). W styczniu 2016 r. premier Ch. Michel, wyrażając oburzenie na ataki na kobiety w Kolonii podczas zakończenia roku, wyraził stanowczą opinię, że „równość mężczyzn i kobiet w Belgii nie będzie przedmiotem dyskusji i że nigdy nie pozwoli, aby kobiety były prześladowane $\mathrm{z}$ tego powodu, że są tylko kobietami” „niezależnie od tego, czy jest uchodźcą czy nie, nie ma wyjątków jeżeli chodzi o fundamentalne wartości i wolności" (Wie onze gastvrijheid misbruikt, kan geen bescherming krijgen, 2016). Ponownie, zaznaczył, iż „ludzie, którzy nadużywają naszej gościnności nie mogą uzyskać ochrony. Każdy uchodźca ma obowiązek stosować się do naszych wartości demokratycznych...”, ,[...] odnosimy się do uchodźców z poszanowaniem ich praw i godności. Ale nie jesteśmy naiwni. Humanitaryzm i skuteczna polityka. Nadal będziemy jej bronić" (Ibidem). Podobna była opinia króla Filipa I, który pochwalił rząd i społeczeństwo za godne zachowanie się podczas kryzysu uchodźczego. „Uchodźcy otrzymali godne życie. Bez przemocy i z poszanowaniem naszych wartości demokratycznych" (Ibidem).

Belgowie z coraz większym przekonaniem i zaangażowaniem domagają się, aby imigranci przystosowali się do zasad państwa przyjmującego. Zarówno „nowi” jak i „starsi” Belgowie z drugiego i trzeciego pokolenia są może bardziej tolerowani, ale nadal na ich punkcie istnieje nadwrażliwość społeczna. Już w wielu miastach jak Aalst, Antwerpia, Brugia, Genk, Kortrijk, Leuven, Mechelen i Roeselare istnieją numery interwencyjne, pod które ludzie mogą złożyć swoje skargi. Linia ta rejestruje skargę i szuka rozwiązania. Podejmowane są również inicjatywy zapobiegania dyskryminacji. Praktycznie wszyscy obywatele Królestwa uważają, że życie w Belgii jest wyjątkowo dobre i bezpieczne dla imigrantów - jeśli są skłonni do integracji w nowym środowisku kulturowym.

\section{Sytuacja imigrantów na belgijskim rynku pracy}

Kwestia zatrudnienia w relacjach pomiędzy Belgami a imigrantami posiada pewną specyfiką. Według badań De Vlaamse Migratie- i Integratiemonitor i de federale Socio-Economische Monitoring, w 2012 roku tylko 43\% osób spoza Unii Europejskiej znalazło w Belgii zatrudnienie. Wśród kobiet statystyki zatrudnienia wyglądały gorzej: tylko 32\% wśród kobiet spoza UE znalazło stałą pracę, co windowało wskaźniki bezrobocia w środowiskach emigrantów (Vanduynslager, Wets, Nope, Doyen, 2014).

Niekorzystna sytuacja na rynku pracy dla obcokrajowców, wynika m.in. z kwestii edukacji imigrantów. Niewykwalifikowani i niewykształceni imigranci, nie odpowiadają już na zapotrzebowanie na rynku pracy, na którym nastapiły zmiany technologiczne i przejście do gospodarki opartej na wiedzy. Zwłaszcza w regionie stołecznym Brukseli, nawet dla nisko wykwalifikowanych dwujęzycznych osób, pracy często nie ma, a jakość kształcenia i brak kwalifikacji są alarmujące, inaczej dzieje się w innych regionach. W wielu biedniejszych dzielnicach Brukseli stopa bezrobocia wśród młodych ludzi wzrasta. Zdarzają się również często przypadki, że imigranci sugerują, iż 
nie otrzymali pracy z powodu rasizmu. Jozef De Witte, dyrektor Centrum Równych Szans i Zwalczania Rasizmu utrzymuje, że w pewnym sensie społeczeństwo jest nadal rasistowskie, gdyż „nadal pozostaje normą, że Flamand jest biały, heteroseksualny i pełnosprawny...” (Rabaey, 2014).

Problem na rynku pracy dla osób obcego pochodzenia, osiagnął takie rozmiary, że polepszenie ich sytuacji może tylko nastapić poprzez kompleksowe podejście ze strony państwa jak np. poprzez edukację, dbałość o język, staże itp. Z pewnością cele te mogą zostać osiagnięte i mogą uchronić przed dyskryminacją w zatrudnieniu. Integracja może stać się rzeczywistością tylko wtedy, gdy każdy aktor, „duży” i ten „mały”, publiczny i prywatny będzie uczestniczył w zmianach.

\section{Ewolucja międzynarodowej imigracji}

W 2014 r., w samej Flandrii odnotowano 46811 obcokrajowców z zagranicy przy dłuższych pobytach niż 3 miesiące. Liczba cudzoziemców wrosła pomiędzy 2000 a 2014 r. praktycznie dwukrotnie, a faktyczny wzrost zaobserwowano do $2011 \mathrm{r}$. (w 2003 r. i 2009 r. odnotowano niewielki spadek imigracji). W 2014 r. odnotowano niewielki wzrost $\mathrm{w}$ porównaniu z rokiem 2013. Liczba imigrantów w regionie Flandrii rozwijała się w sposób równoległy do liczby w Belgii. Także w roku 2014 w Belgii ogółem odnotowano 110201 imigrantów, co odpowiada prawie dwukrotnej liczbie od roku 2000 (Myria, 2015, s. 6). W regionie Flamandzkim ponad 40\%, w regionie stołecznym Brukseli między 35\% a 40\%, a w Walonii około 20\%. Proporcjonalnie do liczby ludności imigracja zdecydowanie najwyższa była w regionie stołecznym Brukseli (Broucke, Noppe, Suyck i in., 2015, s. 24-26).

Wykres 1. Liczba imigrantów w Belgii w latach 2000-2014 (w tys. osób)

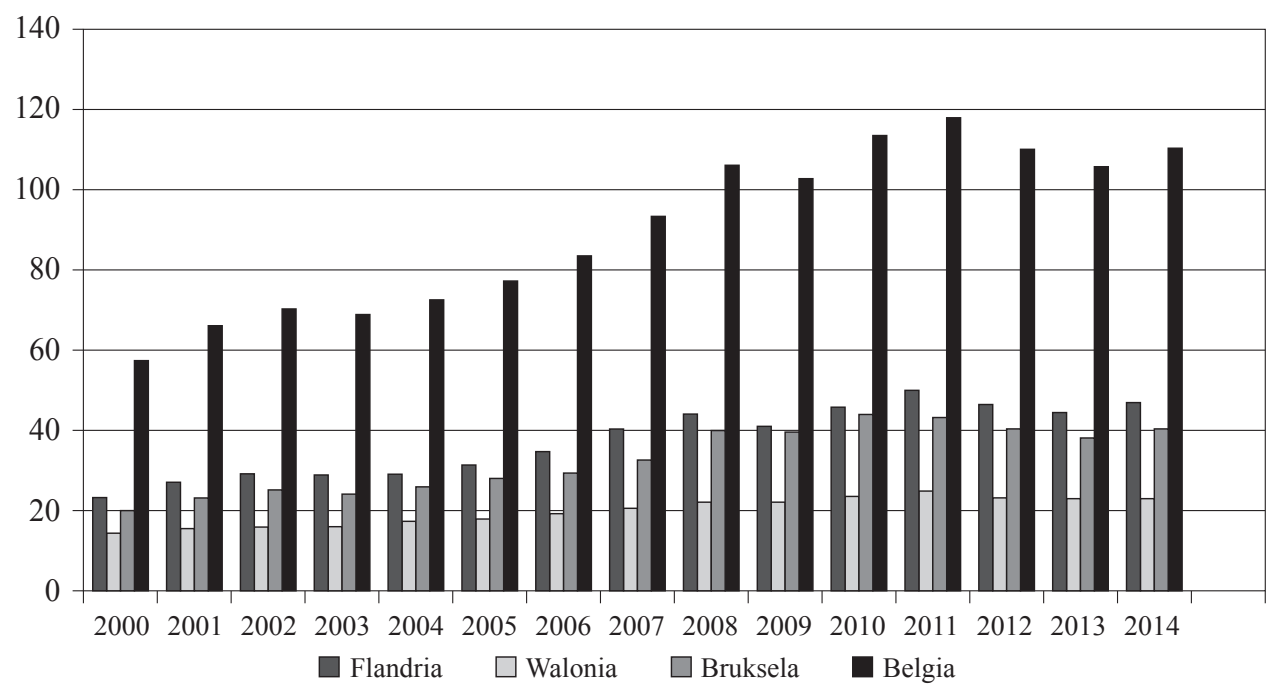

Źródło: Broucke, Noppe, Suyck (i in.) (2015), Vlaamse Migratie en Intergratiemonitor 2015, s. 26. 
Warto uwzględnić, iż podział na grupy narodowościowe różnił się nieco pomiędzy regionami. W Walonii udział z krajów sąsiednich był o wiele większy niż we Flandrii i Brukseli. Udział imigrantów państw Południa-UE w Brukseli był wyższy niż w Walonii czy Flandrii. Odsetek imigrantów z państw UE13 i państw azjatyckich był najwyższy we Flandrii. Z kolei odsetek imigrantów z grupy państw Maghrebu był tam najniższy. Ogólnie rzecz biorąc, Belgia charakteryzowała się największą imigracją z innych państw członkowskich UE; w 2014 roku udział imigrantów z UE w Belgii wynosił 69\%, a w samej Flandrii do 67\% (Ibidem).

Tabela 1

Udzial grup narodowościowych imigrantów w Belgi w 2014 r.

\begin{tabular}{|l|r|r|r|r||}
\hline & Flandria & Walonia & Bruksela & \multicolumn{1}{c||}{ Belgia } \\
\hline Razem UE & $\mathbf{3 1 4 5 6}$ & $\mathbf{1 5 4 6 0}$ & $\mathbf{2 9 ~ 0 3 4}$ & $\mathbf{7 5 9 5 0}$ \\
\hline Sąsiedzi* & 10316 & 6930 & 8736 & 25982 \\
\hline Zachód-Północ UE15** & 1310 & 580 & 1711 & 3601 \\
\hline Południe-UE15*** & 5421 & 4403 & 7481 & 17305 \\
\hline UE13*** & 14409 & 3547 & 11106 & 29062 \\
\hline Razem bez UE & $\mathbf{1 5 3 5 5}$ & $\mathbf{7 5 1 3}$ & $\mathbf{1 1 3 8 3}$ & $\mathbf{3 4 2 5 1}$ \\
\hline Europa bez UE & 1624 & 617 & 1064 & 3305 \\
\hline Turcja & 939 & 364 & 400 & 1703 \\
\hline Maghreb & 1900 & 1730 & 2370 & 6000 \\
\hline Państwa azjatyckie & 5478 & 1126 & 3759 & 10363 \\
\hline Państwa afrykańskie & 2599 & 1861 & 1696 & 6156 \\
\hline Pozostałe państwa & 2815 & 1815 & 2094 & 6724 \\
\hline Lączna suma & $\mathbf{4 6 ~ 8 1 1}$ & $\mathbf{2 2 9 7 3}$ & $\mathbf{4 0 4 1 7}$ & $\mathbf{1 1 0} \mathbf{2 0 1}$ \\
\hline
\end{tabular}

* Holandia, Francja, Niemcy i Luksemburg.

** Irlandia, Wielka Brytania, Austria, Dania, Szwecja i Finlandia.

*** Włochy, Hiszpania, Portugalia i Grecja.

**** Estonia, Łotwa, Litwa, Polska, Czechy, Słowacja, Węgry, Słowenia, Bułgaria, Rumunia, Malta, Cypr i Chorwacja.

Źródło: Broucke, Noppe, Suyck (i in.) (2015), Vlaamse Migratie en, s. 30.

Odnosząc się do demograficznego profilu imigrantów, to napływ imigrantów w całej Belgii charakteryzował się niemal równym podziałem według płci, podobnie jak w innych regionach. Ten sam wskaźnik widoczny był również w ogólnej UE15. W regionie Flandrii w 2014 roku można było wyróżnić nieco więcej mężczyzn (51,1\%) niż kobiet (48,9\%). Wśród grup narodowościowych spoza UE, było wręcz przeciwnie. Kobiety tutaj stanowiły większość z wyjątkiem grupy państw afrykańskich. Przewaga mężczyzn była stosunkowo wysoka tylko w grupie państw UE13. Natomiast w grupie państw azjatyckich, przewagę stanowiły kobiety.

Tabela 2

Demograficzny profil imigrantów według płci w Belgii w 2014 roku (w tys.)

\begin{tabular}{|l|c|c|}
\hline & Kobiety & Mężczyźni \\
\hline Flandria & 22895 & 23916 \\
\hline Walonia & 11563 & 11410 \\
\hline Bruksela & 19964 & 20453 \\
\hline Belgia & 54422 & 55779 \\
\hline
\end{tabular}

Źródło: Broucke, Noppe, Suyck (i in.) (2015), Vlaamse Migratie en, s. 34. 
Wykres 2. Demograficzny podzial imigrantów według płci w 2014 roku (w \%)

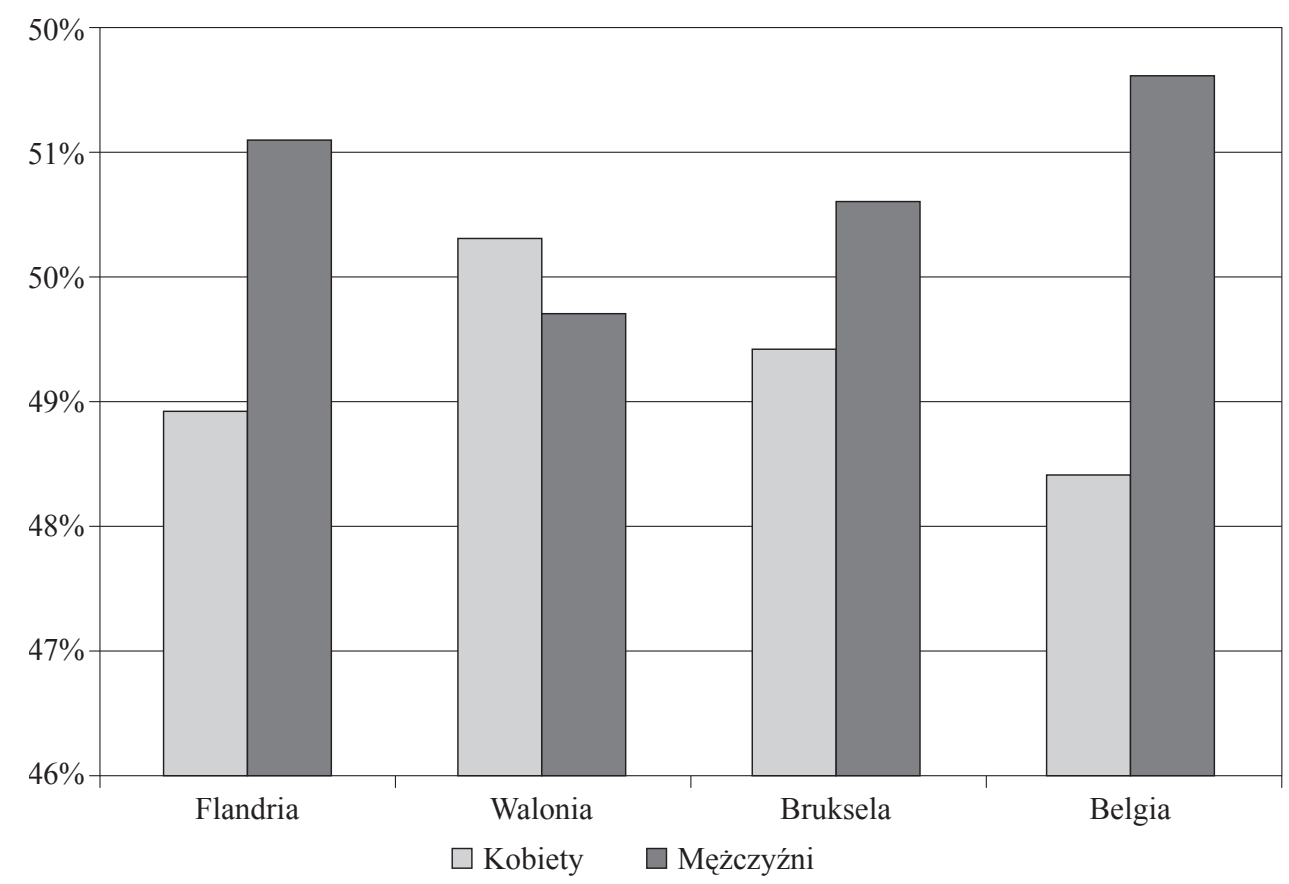

Źródło: Broucke, Noppe, Suyck (i in.) (2015), Vlaamse Migratie en, s. 34.

\section{Narodowość azylantów}

Każdy obcokrajowiec przyjeżdżający do Belgii, może ubiegać się o azyl, o odpowiednią ochronę rządu belgijskiego. Wnioskodawca przechodzi kilka etapów, od wniosku o azyl do ostatecznej decyzji. Kroki te stanowią tzw. procedurę azylową. Państwo belgijskie bada czy cudzoziemiec spełnia kryteria określone w Konwencji Genewskiej z 1951 r. dotyczącej statusu uchodźców.

Państwa pochodzenia azylantów w Belgii różnią się znacznie w miarę upływu czasu. W 2014 roku najwyższy procent stanowiła grupy Afgańczyków i Syryjczyków (11\%), następnie Irakijczyków (7\%), mieszkańców Gwinei i Rosji (6\%), Erytrejczyków i Kongijczyków (4\%), mieszkańców Kosowa, Albanii i Ukrainy (3\%) (Broucke, Noppe, Suyck i in., 2015, s. 50-51; Statistiques d'asile rapport mensuel janvier 2014). W ciagu ostatnich lat nastapiły tendencje wzrostowe lub spadkowe dla tych narodowości. Liczba wniosków od Afgańczyków gwałtownie wzrosła, ale w 2014 roku była znacznie niższa niż w roku 2011. Także liczba wniosków obywateli syryjskich wzrosła kilkukrotnie w latach 2015-2016, chociażby w porównaniu z rokiem 2014. Liczba osób ubiegających się o azyl z Erytrei czy Ukrainy wzrosła również w 2014 r. (także po 2014 r.), w porównaniu do 2011.

Wobec innych narodowości odnotowano spadek liczby wniosków o azyl w roku 2014 w porównaniu do 2011 roku, z takich państw jak Irak, Gwinea, Kongo, Rosja, 
Kosowo i Albania. Spadek liczby imigrantów z Kosowa i Albanii, może być związany z umieszczeniem tych państw na „liście bezpiecznych krajów”. Dlatego też ochrona międzynarodowa nie jest konieczna wobec obywateli tych państw znajdujących się na liście bezpiecznych państw. W związku z tym rozpatrywanie wniosków następuje podczas specjalnej procedury.

Przechodząc do 2015 roku należy odnotować, że zarejestrowano 35476 wniosków o azyl. Było to 106,1\% więcej niż w roku 2014. Szczególnie w drugiej połowie 2015 roku nastąpił gwałtowny wzrost liczby osób ubiegających się o azyl. Większość ubiegających się o azyl pochodziło z obszarów, na których występują konflikty: 21,8\% osób z Iraku, 21,3\% z Syrii i Afganistanu, które mieściły się w pierwszej trójce krajów pochodzenia (20\%) (Asielstatistieken, Cijfers, 2015). Oczywiście, pojawiło się coraz więcej Syryjczyków występujących o azyl pod koniec 2015 r. (Fedasil, Maandrapport - Rapport Mensuel, 2016). Jeszcze w styczniu liczba wniosków o azyl wynosiła 167, podczas gdy w grudniu było już 718 wniosków. W przypadku Irakijczyków, duża liczba wniosków o azyl była w sierpniu i wrześniu (odpowiednio 2167 i 2207 wniosków o azyl). Następnie liczba zmniejszyła się ponownie. Od października ponownie nastąpił wyraźny wzrost afgańskich azylantów (do 1955 wniosków w grudniu) (Jaarlijkse atatistieken - Asielaan vragen (2016)).

Wykres 3. Liczba wniosków o azyl w 2015 r.

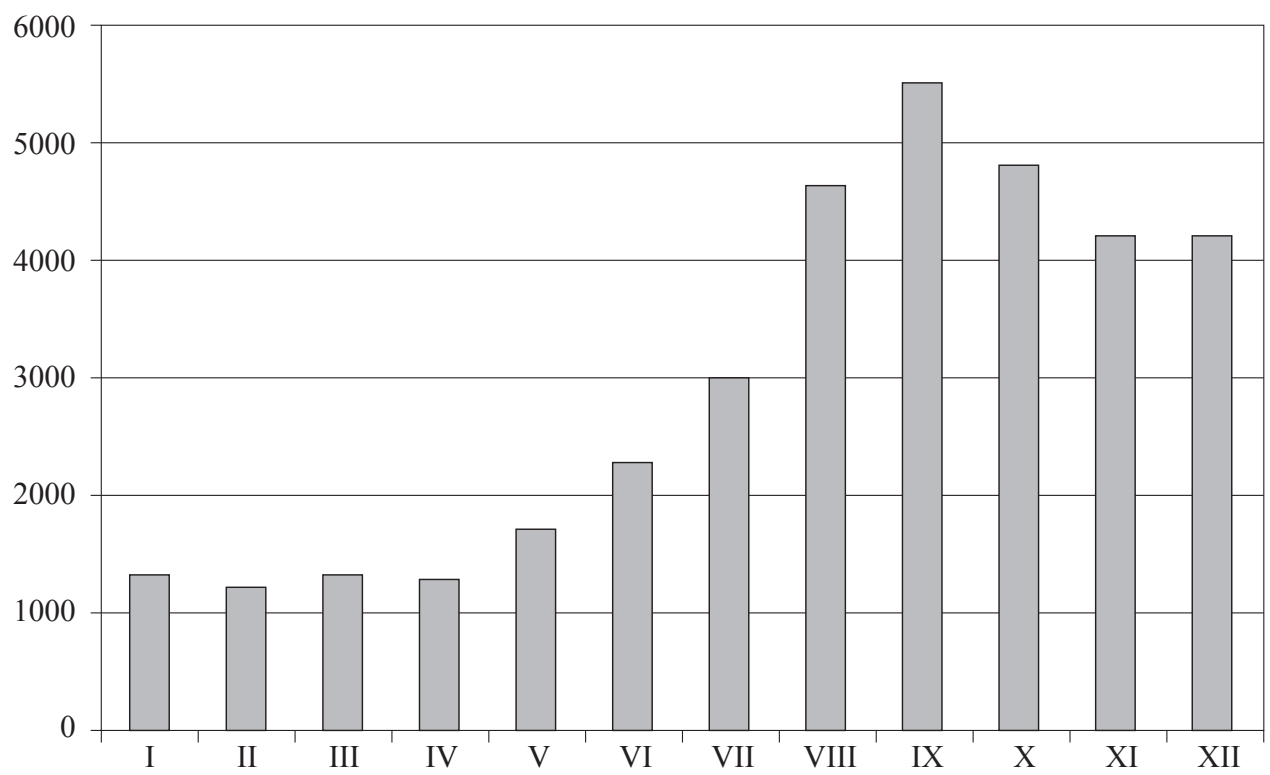

Źródło: Opracowanie własne na podstawie danych: Asielstatistieken (2015), Cijfers, http://www.cgvs.be/ $\mathrm{nl} /$ actueel/asielstatistieken-overzicht-2015, Bruksela.

Bezpieczeństwo i prawa człowieka w Syrii nie są przestrzegane, dlatego też oczywistym faktem jest, aby obywatele syryjscy potrzebujący ochrony międzynarodowej ją otrzymali. W 2015 roku wobec prawie każdego syryjskiego obywatela zastosowano status ochronny (97,64\%), wydano 2443 decyzje o przyznaniu statusu 
uchodźcy oraz 283 decyzji o przyznaniu statusu ochrony uzupełniającej (Asielstatistieken, 2015).

Ponadto, w 2015 roku zwrócono większą uwagę na osoby małoletnie bez opieki ubiegające się o azyl: zarejestrowano około 3919 indywidualnych wniosków o azyl. Po zakończeniu dochodzenia przez odpowiednie służby odkryto, że prawie jedna czwarta $\mathrm{z}$ nich były to dorosłe osoby w momencie złożenia wniosku o udzielenie azylu. Ile osób faktycznie nieletnich było, tego do końca nie wiadomo (Asielstatistieken, 2015).

Podobnie jak w większości państw europejskich, od stycznia 2016 r. nastąpił niewielki spadek wniosków o azyl. Wynikało to w dużej mierze z zamknięcia szlaku bałkańskiego. Granice zostały zamknięte przez Macedonię, Węgry i Słowenię. Jeszcze większy spadek odnotowano po porozumieniu Unii Europejskiej z Turcją: Grecja w ten sposób wysyła uchodźców z powrotem do Turcji, a w zamian za jednego syryjskiego uchodźcę odesłanego do Turcji, kraje UE będą odbierały z Turcji jednego Syryjczyka przebywającego w jednym z tureckich obozów dla uchodźców. W związku z tym ma to zmniejszyć liczbę osób nielegalnie przekraczających granicę oraz zaprowadzić ład w chaosie kryzysu migracyjnego.

Wykres 4. Liczba wniosków o azyl w pierwszej połowie 2016 r.

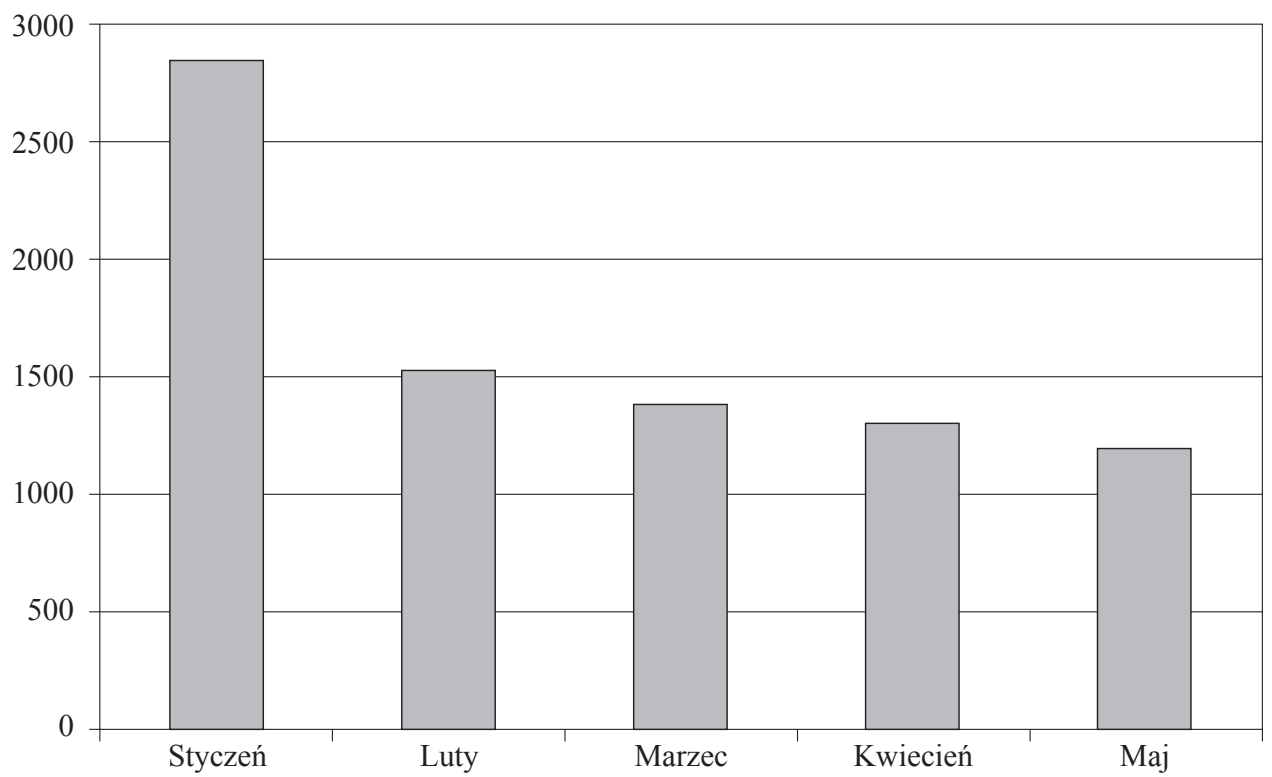

Źródło: Opracowanie własne na podstawie danych: Asielstatistieken (2016), Cijfers, http://www.cgvs.be/ nl/cijfers, Bruksela.

W styczniu 2016 r. więcej wniosków o azyl otrzymano od mężczyzn niż kobiet, a proporcja ta wynosiła $70,8 \%$ do $29,2 \%$. W styczniu także wyróżniono 288 wnioski o azyl od dzieci i młodzieży będących bez opieki rodzica, co stanowiło spadek o $64,2 \%$ w porównaniu z liczbą z grudnia 2015 r., kiedy to otrzymano 804 wnioski (Asielstatistieken, 2016). W kolejnych miesiącach, można zauważyć niewielki wzrost składanych wniosków o azyl wśród płci żeńskiej, natomiast 
w marcu jeszcze nastąpił największy wzrost wniosku o azyl obu płci (Afganistan, Syria, Irak).

\section{Wykres 5. Demograficzny profil imigrantów według płci w Belgii w 2016 roku}

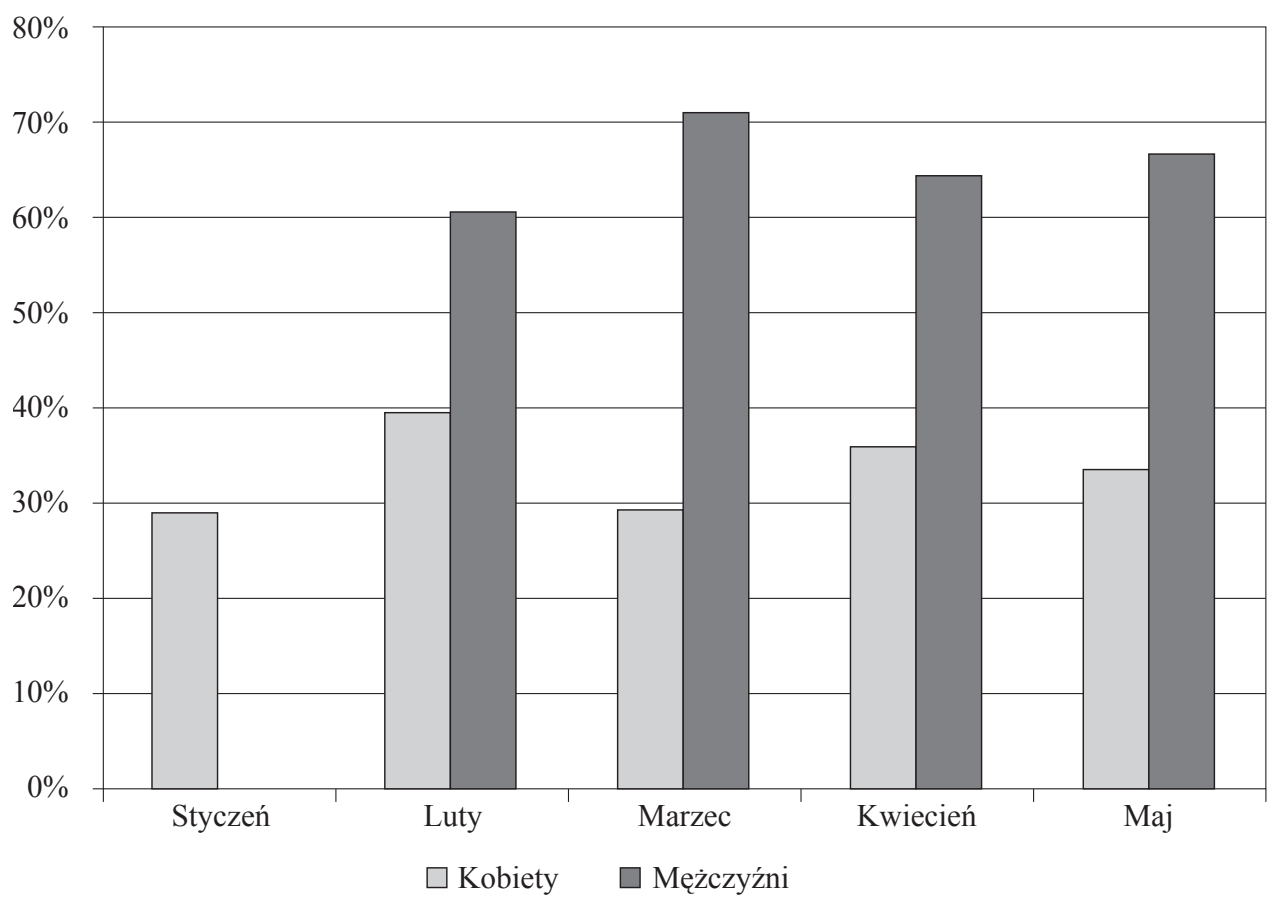

Źródło: Opracowanie własne na podstawie danych: Asielstatistieken (2016), Cijfers, http://www.cgvs.be/ nl/cijfers, Bruksela.

\section{Procedura rejestracji imigrantów}

W marcu 2016 r. poinformowano na łamach prasy belgijskiej, że Federalne Centrum Migracji złożyło skargę przeciwko państwu belgijskiemu w związku z niedoinformowaniem azylantów o ich możliwościach wnioskowych w tym państwie. Natomiast, jeżeli oficjalnie poinformowano wnioskodawców o procedurze azylowej to były to głównie informacje „odstraszające” tj. belgijski system azylowy jest zagrożony i że ta sytuacja ma negatywne konsekwencje dla rozpatrywania wniosku o azyl w Belgii (Paelinck, 2016).

Pod koniec ubiegłego i na początku tego roku podczas rejestracji imigrantów stosowano odpowiednie kolory kartek, odpowiadające konkretnej dacie obecności przez imigranta w urzędzie oraz czy dana osoba kwalifikuje się na otrzymanie miejsca noclegowego w danym ośrodku. Dzięki temu, można było szybko skontrolować czy dana osoba jest obecna we właściwym terminie. Niestety, problem pojawił się wówczas, kiedy na karcie nie widniały dane osobowe, a jeżeli już były to po prostu ktoś inny (nie czekając na swoją kolej) użył karty. Liczba imigrantów w tym czasie była znacząca 
i zarówno policja, jak i pracownicy socjalni próbowali kontrolować sytuację. Kiedy policjanci zauważyli nieprawidłowości w związku z przekazywaniem przez imigrantów nie swoich kart, natychmiast reagowano. Inaczej sytuacja wyglądała z pracownikami socjalnymi. Kolejną problematyczną sprawą było to, że trudno było na przykład osobom z Afganistanu uzyskać azyl (akceptowani byli głównie Syryjczycy). Następnie trzeba było również oddzielnie dla tych dwóch grup szukać różnych tłumaczy (perskiego, arabskiego i innych), ponieważ częstą praktyką stosowaną przez imigrantów, było zmienianie swoich danych osobowych, wieku czy przynależności państwowej.

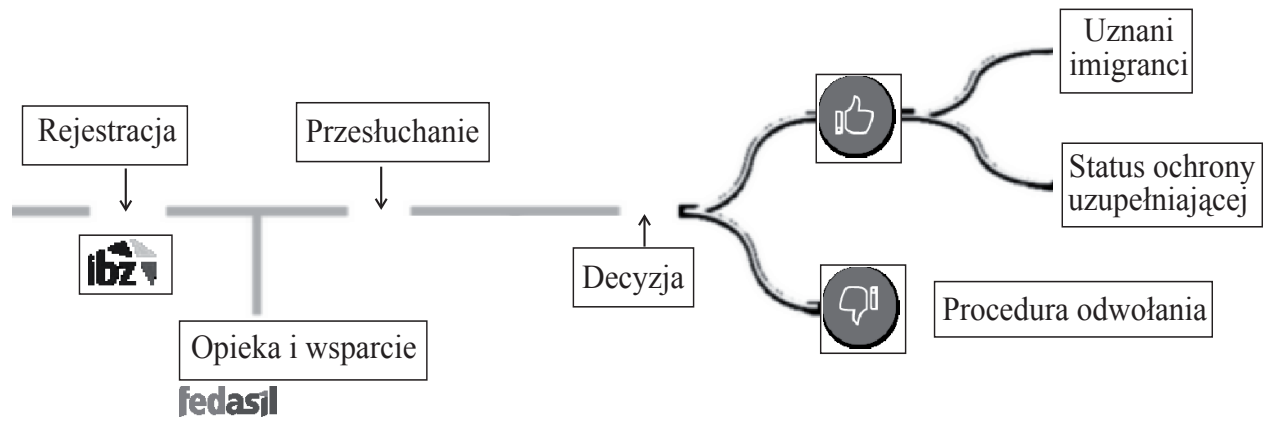

Grafika 1. Postępowanie proceduralne podczas składania wniosków o azyl

Źródło: Commissariaat-generaal voor de vluchtelingen en de staatlozen Asielprocedure, http://www.cgvs. be/nl/asiel/de-registratie-van-de-asielzoeker, Bruksela.

W pierwszej fazie Rejestracja w Urzędzie Imigracji następuje rejestracja wniosku imigranta ubiegający się o azyl. Kolejno określa się język, w którym odbywać się będzie postępowanie, a dalej kontynuuje się zadawanie pytań dotyczących danych osobowych wnioskodawcy. Po rejestracji, wnioskodawca przedstawia wszystkie istotne dokumenty, które ma ze sobą. Po zarejestrowaniu, imigrant może skontaktować się z Fedasil o miejsce w ośrodku, materialną pomoc i wskazówki dotyczące pomocy społecznej, prawnej i medycznej. Biura znajdują się w tym samym budynku. Belgia ma około 50 ośrodków przyjmujących osoby ubiegających się o ochronę międzynarodową, zarządzanych przez Fedasil lub jeden z jego partnerów (na przykład Czerwony Krzyż). Następnie Przesłuchanie, jest ważnym momentem w procedurze azylowej. W wywiadzie, wnioskodawca może wyjaśnić, dlaczego opuścił swój kraj pochodzenia. Kolejno w fazie podejmuje się decyzję tak szybko jak to możliwe. W niektórych przypadkach może to trwać nieco dłużej, aby wnioskodawca otrzymał decyzję. Jeżeli został przyznany azyl imigrantowi to jest on uprawniony do nieograniczonego zamieszkania w Belgii. Uznani podlegają prawu belgijskiemu i muszą przestrzegać prawa jak obywatele belgijscy. W przypadku ochrony uzupetniajacej, osoba otrzymuje zezwolenia na zamieszkanie na czas określony jednego roku. Niektóre przepisy z państwa pochodzenia, nadal są stosowane: takie jak prawa pełnoletniości lub ważności małżeństwa (w tym przypadku zapowiada się zmianę, aby nie uznawać małżeństw osób bardzo młodych). Jeżeli imigrant nie zgadza się z decyzją o odrzuceniu wniosku, może (ze swoim radcą prawnym) złożyć kasację do odpowiedniej instytucji (Asielprocedure). 


\section{Zakończenie}

Nie ulega wątpliwości, że kwestia przyjmowania uchodźców w Europie wywołuje wiele emocji i rodzi sporo kontrowersji. Sprzeciw wobec imigracji w wielu państwach europejskich nie jest motywowany wyłącznie względami społeczno-ekonomicznymi, ale także kulturowymi - obawą przed utratą tożsamości kulturowej czy własnego wizerunku.

W przypadku Belgii kryzys imigracyjny nie był aż tak dotkliwy jak w pozostałych państwach unijnych, głównie ze względu na ograniczoną skalę tego zjawiska. Przez emigrantów za najbardziej atrakcyjne kraje osiedlania się uchodziły Szwecja, Niemcy, Austria, Wielka Brytania i w mniejszym stopniu Francja. Jednakże w samej Belgii nie brakowało różnych incydentów ze strony przybyłych imigrantów czy manifestacji obywateli belgijskich przeciwko przyjmowaniu imigrantów. W 2015 r. opublikowano badania dla poszczególnych państw, z których wynika, że połowa rozwiniętych państw postrzega imigrację negatywnie. Odpowiednio 61\% Belgów uważa, że w państwie jest zbyt wielu imigrantów. Kolejno zapytani, czy imigracja ma negatywny wpływ na państwo, $58 \%$ Belgów odpowiedziało że - tak. Nadal ponad połowa Belgów (52\%) uważa, że trudniej jest znaleźć pracę po przybyciu migrantów, a 56\% uważa, że imigranci stanowią obciążenie dla państwa. Zaledwie $12 \%$ ankietowanych uważało, że imigranci mają pozytywny wpływ na rozwój państwa (Ipsos Public Affairs, 2015).

Uważa się jednak, że Belgia pozostanie państwem docelowej imigracji, pytanie brzmi, czy jest na to wyzwanie dostatecznie przygotowana. Dziś można powiedzieć o pogłębiającej się alienacji i braku solidarności wobec nowych imigrantów nie tylko wśród rdzennych Belgów, ale także u Belgów z „historią migracji”. Krytycy podkreślają, że belgijski system przyjmowania uchodźców okazał się zupełnie niewydolny, i cechowała go raczej doraźna improwizacja. Urząd dla cudzoziemców nie mógł sobie poradzić $\mathrm{z}$ ograniczonym przecież kryzysem imigracyjnym. $\mathrm{Z}$ jednej strony $\mathrm{w}$ wielu komentarzach w prasie czy w telewizji z ust polityków czy urzędników często padały słowa iż państwo belgijskie ma już spore doświadczenie z przeszłości z radzeniem sobie z napływem imigrantów i sytuacja z czasem zostanie opanowana. $Z$ drugiej strony codzienna praktyka pokazała zupełnie coś odwrotnego, ale ze względu na „polityczną poprawność" media tzw. głównego nurtu nie podnosiły tego tematu, pozostawiając wolne pole dla populistów i demagogów.

Coraz więcej uchodźców powraca do swoich domów. W 2015 roku na taki krok zdecydowało się 4 tys. osób. Tylko w pierwszych pięciu miesiącach 2016 r., decyzję o powrocie podjęło dalszych 2 tys. uchodźców. Powodem powrotów do swoich krajów jest przede wszystkim pomoc, jaką dostali od Belgii. Afgańczycy czy Irakijczycy mogą liczyć na to, że to państwo belgijskie opłaci im i całej ich rodzinie podróż do domu, a sam powrót odbędzie się w sposób dyskretny i spokojny. Powracający otrzymują także belgijskie wsparcie na otwarcie niewielkiego biznesu czy na odnowienie mieszkania. Uchodźcy mogą zwracać się o pomoc do tzw. okienek powrotów, które powstały już w kilku miastach. Władze Brukseli zamierzają rozwijać program reintegracji uchodźców w ich kraju pochodzenia. Twierdzą, że jego koszty są mniejsze niż utrzymywanie migrantów w Belgii (Uchodźcy wracaja do domów, 2016). 


\section{Bibliografia}

Aiyar S., Barkbu B., Batini N. (2016), The Refugee Surge in Europe: Economic Challenges Asielprocedure, http://www.cgvs.be/nl/asiel/de-registratie-van-de-asielzoeker, Bruksela.

Asielstatistieken (2016), Cijfers, Bruksela, http://www.cgvs.be/nl/cijfers.

Baert D., De Roy L., Sluit migranten op in kamp zoals Guantanamo, maar dan zonder folteren, http:// deredactie.be/cm/vrtnieuws/binnenland/2.40548?eid=1.2408759.

Broucke van den S., Noppe J., Suyck K. (i in.) (2015), Vlaamse Migratie en Intergratiemonitor 2015.

Bruggeman F. (2016), Aantal asielaanvragen in ons land blijft dalen, http://deredactie.be/cm/vrtnieuws/binnenland/2.40548.

Brussels Observatorium voor de Werkgelegenheid, Territoriale benadering van de werkloosheid van allochtone vrouwen of vrouwen van allochtone afkomst in het Brussels Gewest (2012), Bruksela.

Commissariaat-generaal voor de vluchtelingen en de staatlozen, Asielprocedure, http://www.cgvs. be/nl/asiel/de-registratie-van-de-asielzoeker, Bruksela.

Commission presents options for reforming the Common European Asylum System and developing safe and legal pathways to Europe (2016), Bruksela, http://europa.eu/rapid/press-release_IP16-1246_en.htm.

Erfenis uit het verleden die je in twee jaar niet kan opkuisen (2016), „Knack”, 08.08.2016, http:// www.knack.be/nieuws/belgie/theo-francken-erfenis-uit-het-verleden-die-je-in-twee-jaarniet-kan-opkuisen/article-normal-737291.html.

Europe's Muslim hate the West (2015), http://www.politico.eu/article/brussels-attacks-terrorism-europe-muslims-brussels-attacks-airport-metro/, Bruksela.

Evolutie van de Brusselse arbeidsmarkt (2015), Styczeń, Bruksela.

Federaal Agentschap voor de opvang van azielzoekers, http://fedasil.be/nl/figures, Bruksela.

Frank S. (2015), Belgen staan erg negatief tegenover migratie, „De Redactie”, 08.08.2015, http:// deredactie.be/cm/vrtnieuws/binnenland/1.2410072.

Hoe Molenbeek internationaal op de kaart werd gezet (2015), „De Standard”, 15.11.2015, http:// www.standaard.be/cnt/dmf20151115_01972039.

Ipsos Public Affairs (2015), http://www.ipsos-na.com/news-polls/pressrelease.aspx?id=6930.

Jaarlijkse atatistieken - Asielaan vragen (2016), https://dofi.ibiz.be/sites/drzone/NL/Statistieken/ Pages/Asiel.aspk.

Koopmans R. (2013), Fundamentalismus und Fremdenfeindlichkeit Muslime und Christen im europäischen Vergleich, https://www.wzb.eu/sites/default/files/u252/s21-25_koopmans.pdf.

Maandrapport - Rapport Mensuel, December 2015 (2016), Fedasil, Bruksela.

Myria, Migratie in cijfers en in rechten 2015, www.myria.be/nl/publicaties/migratie-in-cijfers-enin-rechten-2015.

Opvangcrisis zal alleen maar moeilijker worden (2015), „Knack”, 06.09.2015, http://www.knack. be/nieuws/belgie/charles-michel-opvangcrisis-zal-alleen-maar-moeilijker-worden/articlenormal-600423.html.

Paelinck G., Migratiecentrum dient een klacht in tegen België: „Info misleidt asielzoekers”, http:// deredactie.be/cm/vrtnieuws/binnenland/2.40548.

Rabaey M. (2014), Jozef De Witte verklaart: daarom telt België zo veel Syriëstrijders, „De Morgen”, 30.09.2014.

Reybrouck van D. (2011), Congo. Een geschiedenis. 30e dr. Amsterdam: De Bezige Bij.

STATISTIQUES D'ASILE RAPPORT MENSUEL JANVIER 2014, http://www.west-info.eu/asylumapplications-down-inbelgium/statistiques_asile_janvier_2014_externe_tcm126-242086/. 
UNHCR (2014), UNHCR Global Trends. Forced Displacement in 2014, www.unhcr.org/556725e69.html. Uchodźcy wracaja do domów. Z Belgii wyjechało już 4 tys. osób (2016), http://www.rmf24.pl/fakty/ swiat/news-uchodzcy-wracaja-do-domow-z-belgii-wyjechalo-juz-4-tys-osob,nId,2230319.

Van Daele J. (2010), Congolezen in België: Racisme is een gemiste kans voor iedereen, http://www. mo.be/magazine/juni-2010/congolezen-belgie-racisme-een-gemiste-kans-voor-iedereen.

Vanduynslager L., Wets J., Nope J., Doyen G. (2014), Vlaamse Migratie en Imigratie 2013, Bruksela.

Vanthemsche G. (2011), Van de Belgische Koloniale Biografie naar het Biografisch Woordenboek van Belgen Overzee, Bruksela.

Vlaamse Migratie - en Integratiemonitor 2013 (2013), Bruksela.

Wie onze gastvrijheid misbruikt, kan geen bescherming krijgen, http://www.hln.be/hln/n1/34662/ Vluchtelingencrisis/article/detail/2599354/2016/01/28/Wie-onze-gastvrijheid-misbruiktkan-geen-bescherming-krijgen.dhtml.

Wil geen Guantanamo in België (2016), „Knack” 31.08.2016, http:/www.knack.be/nieuws/belgie/ premier-michel-wil-geen-guantanamo-in-belgie/article-normal-746791.html.

\section{Streszczenie}

Belgia nie znalazła się bezpośrednio w centrum trudnej sytuacji kryzysowej związanej z emigrantami w latach 2015-2016. Powszechnie jednak uważa się, że pomimo doświadczenia z przeszłości związanych z przyjmowaniem imigrantów w wielu obszarach struktury państwa zawiodły. W artykule, została przedstawiona przeszłość kolonialna Królestwa Belgijskiego, ewolucja międzynarodowej imigracji od roku 2000 do roku 2014, a także szerzej omówiono sytuację imigrantów na belgijskim rynku pracy w latach 2015-2016.

Słowa kluczowe: Belgia, imigranci, kryzys imigracyjny

\section{The Kingdom of Belgium's approach towards the immigration crisis (2015-2016)}

\section{Summary}

Belgium was not in a difficult situation during heavy influx of immigrants but on the other hand, in some areas, Belgium has failed in spite of past experience with immigrants. This article presents the colonial past of Belgium, the evolution of international migration since the year 2000-2014 as well as more broadly discussed the situation of migrants on the Belgian labor market in the years 2015-2016.

Key words: Belgium, immigrants, the immigration crisis 